ISSN: 2302-8556

E-Jurnal Akuntansi Universitas Udayana

Vol.26.3.Maret (2019): 2070 -2097

DOI: https://doi.org/10.24843/EJA.2019.v26.i03.p15

\title{
Pengaruh Board Diversity Pada Nilai Perusahaan Dalam Perspektif Corporate Governance
}

\author{
Ni Luh Putu Purna Yogiswari ${ }^{1}$ \\ I Dewa Nyoman Badera ${ }^{2}$ \\ ${ }^{1,2}$ Fakultas Ekonomi dan Bisnis Universitas Udayana (Unud), Bali, Indonesia \\ e-mail: purnayogiswari07@gmail.com
}

\begin{abstract}
ABSTRAK
Board composition merupakan salah satu isu khusus dari corporate governance. Penelitian ini bertujuan untuk menemukan bukti empiris mengenai pengaruh board diversity yang diproksikan dengan gender diversity, nationality diversity, latar belakang pendidikan, dan proporsi outside directors pada nilai perusahaan. Penelitian ini dilakukan pada seluruh perusahaan manufaktur sektor industri dasar dan kimia yang terdaftar di Bursa Efek Indonesia dengan periode pengamatan yakni 3 tahun yaitu periode 2015-2017. Metode penentuan sampel menggunakan teknik purposive sampling. Sampel penelitian ini berjumlah 39 perusahaan dengan jumlah pengamatan sebanyak 117 sampel. Berdasarkan hasil analisis, dapat disimpulkan bahwa gender diversity dan proporsi outside directors tidak berpengaruh pada nilai perusahaan sedangkan ada pengaruh positif antara nationality diversity dan latar belakang pendidikan dengan nilai perusahaan.
\end{abstract}

Kata Kunci : Board diversity, corporate governance, dan nilai perusahaan.

\begin{abstract}
Board composition is one particular issue regarding corporate governance. This study aims to find empirical evidence regarding the effect of board diversity proxied by gender diversity, nationality diversity, educational background, and the proportion of outside directors on firm value. This research was conducted in basic industrial and chemical manufacturing companies listed on the Indonesia Stock Exchange with an observation period of 3 years, those of from 2015-2017. The method of determining the sample uses a purposive sampling. The sample of this study amounted to 39 companies with a total of 117 samples. Based on the results of the analysis, it can be concluded that gender diversity and the proportion of outside directors have no effect on firm value while there is a positive effect between nationality diversity and educational background on firm value.
\end{abstract}

Keywords: Board diversity, corporate governance, and firm value.

\section{PENDAHULUAN}

Pada tahun 1997, terjadi krisis ekonomi yang mengakibatkan terpuruknya kondisi perekonomian di beberapa negara. Penelitian yang dilakukan oleh McKinsey \& Company (2002) serta Riyanda \& Indriani (2013) menyatakan bahwa penerapan tata 
kelola yang tidak baik dalam perusahaan dapat menyebabkan krisis ekonomi. Teori agensi sering digunakan oleh para peneliti untuk menjelaskan hubungan mengenai anggota dewan dan nilai perusahaan. Agency theory menyebutkan bahwa terdapat pemisahaan kepemilikan principal dengan agent. Pemisahan kepemilikan ini akan dapat memunculkan suatu konflik, dimana untuk mengatasi konflik tersebut maka perusahaan harus mengeluarkan biaya agensi. Corporate governance sering kali digunakan sebagai alat untuk mengontrol biaya agensi yang timbul dalam perusahaan (Wijaya \& Suprasto, 2015).

Berdasarkan penelitian McKinsey \& Company (2002) memperlihatkan bahwa penerapan tata kelola di dalam perusahaan menjadi fokus utama para investor. Perusahaan-perusahaan yang menerapkan tata kelola dengan buruk akan cenderung dihindari oleh para investor. Penerapan tata kelola perusahaan bisa dicerminkan pada nilai perusahaan yang dilihat dari harga saham perusahaan yang bersangkutan di pasar (Kusumastuti et al., 2007). Black et al. (2002) menyatakan terdapat dua pandangan yang mampu menjelaskan hubungan mengenai corporate governance dengan nilai perusahaan yakni signalling serta endogenity. Menurut pandangan mengenai signalling, penerapan dari tata kelola perusahaan dapat menaikkan nilai perusahaan karena apabila perusahaan menerapkan tata kelola dengan bagus dapat memberi sinyal positif. Menurut pandangan endogenity, perusahaan yang memiliki nilai pasar tinggi lebih condong memiliki tata kelola yang baik.

Board composition merupakan salah satu isu khusus dari corporate governance (Kusumastuti et al., 2007). Carter et al. (2003) menyatakan komposisi gender, ras, 
ISSN: 2302-8556

E-Jurnal Akuntansi Universitas Udayana

Vol.26.3.Maret (2019): 2070 -2097

serta budaya dari anggota dewan merupakan masalah penting corporate governance yang dihadapi oleh perusahaan modern. Menurut Surya dan Yustiavandana (2006) dalam Rahindayati et al. (2015) peran dewan komisaris dan direksi untuk mengawasi penerapan dari tata kelola perusahaan serta melindungi kepentingan dari para kreditur. Board diversity adalah diversitas dari dewan yang menyangkut mengenai karakteristik dalam penyampaian pandangan mereka (Ararat et al., 2010). Menurut NACD dalam pemilihan anggota dewan harus mempertimbangkan board diversity (Dewi \& Dewi, 2016). Semakin beragam anggota dewan maka alternatif penyelesaian masalah yang dihadapi oleh perusahaan akan semakin banyak (Kusumastuti et al., 2007).

Indonesia menerapkan sistem two tier boards - system continental (sistem dewan dua tingkat) yang mana tingkat pertama yaitu board of commissioner atau dewan pembina atau dewan komisaris. Dewan komisaris ini memiliki kedudukan sebagai supervisor atau pengawas. Tingkat kedua yakni board of directors atau manajemen perusahaan atau direksi. Supervisory boards diketuai oleh chairman atau presiden komisaris atau komisaris utama. Management boards atau dewan direksi diketuai oleh managing director atau chief executive officer (CEO).

Signalling theory menyatakan bahwa manajemen perusahaan akan mempublikasikan suatu pengumuman sebagai sinyal untuk para investor dalam pengambilan keputusan untuk investasi (Jogiyanto, 2013 dalam Ratih \& Damayanthi, 2016). Untuk meminimalisir terjadinya asimetri informasi, manajemen perusahaan secara voluntary akan mengumumkan informasi-informasi terkait perusahaan di 
pasar. Berdasarkan teori sinyal, board diversiy dapat memberikan sinyal positif terkait penerapan corporate governance oleh perusahaan (Wijaya \& Suprasto, 2015).

Pfeffer \& Salancik (1978) mengungkapkan resource dependence theory yang menjelaskan mengenai peran dewan komisaris serta dewan direksi. Perspektif pertama disebut dengan environmental linkage perspective yang menjelaskan bahwa anggota dewan yang memiliki latar belakang yang berbeda secara individual akan menyumbang berbagai sumber daya untuk perusahaan (Siciliano, 1996). Perspektif kedua menjelaskan bahwa internal control dan tindakan administrasi yang dilakukan oleh dewan komisaris dan dewan direksi dapat memengaruhi efisiensi dari perusahaan. Teori tersebut menyatakan dengan adanya struktur anggota dewan yang baik akan dapat memengaruhi nilai perusahaan (Siciliano, 1996).

Studi yang dilansir oleh Catalyst pada tahun 2017 menyatakan bahwa kinerja keuangan akan semakin tinggi apabila wanita menempati posisi top management dalam perusahaan. Pada tahun 2015, Catalyst menemukan bahwa terdapat kesenjangan diantara wanita dengan pria dalam posisi Chief Executive Officer (CEO). Berdasarkan penelitian yang dilakukan Credit Suisse, dari 3000 perusahaan yang ada di dunia proporsi wanita dalam level CEO hanya sebesar 14,7\%. Credit Suisse juga menyatakan bahwa proporsi wanita dalam level CEO terbanyak berada pada sektor industri barang konsumsi (16,3\%), kemudian dari sektor keuangan $(14,8 \%)$, dan yang paling sedikit yakni dari sektor material $(11,6 \%)$.

Lückerath-Rovers (2009) menyatakan ada dua pendapat dari adanya kaitan antara board composition yang berhubungan dengan board diversity dapat 
ISSN: 2302-8556

E-Jurnal Akuntansi Universitas Udayana Vol.26.3.Maret (2019): 2070 -2097

memengaruhi nilai perusahaan. Pendapat pertama yaitu saat mengambil sebuah keputusan penting bagi perusahaan, anggota dewan komisaris serta direksi tentunya memiliki pengaruh besar karena mereka merupakan organ penting perusahaan dan lebih tahu mengenai seluk beluk perusahaan. Pendapat yang kedua menjelaskan bahwa anggota dewan dengan peran pentingnya di dalam perusahaan sebagai pihak yang mewakili kepentingan dari pemegang saham harus dapat menangani tantangan yang dihadapi perusahaan serta memonitor nilai perusahaan.

Beberapa penelitian yang menghubungkan board diversity dan nilai perusahaan (Carter et al., 2003 dan Kusumastuti et al., 2007) mengindikasikan persebaran anggota dewan (board diversity) berpengaruh pada nilai perusahaan. Nguyen \& Faff (2007) mengemukakan bahwa gender diversity bisa meningkatkan nilai pemegang saham karena hadirnya anggota dewan wanita dapat dikaitkan dengan nilai perusahaan yang tinggi. Hasil penelitian Wijaya \& Suprasto (2015) menunjukan bahwa gender diversity berpengaruh positif pada nilai perusahaan, sedangkan diversitas kebangsaan asing, diversitas pendidikan formal, dan proporsi komisaris independen tidak berpengaruh pada nilai perusahaan. Kusumastuti et al, (2007) menyatakan tidak ada hubungan diantara gender diversity dengan nilai perusahaan. Ararat et al, (2010) menyatakan bahwa semakin banyak persentase warga negara asing dalam anggota dewan maka harapan dari para pelaku pasar mengenai kelangsungan hidup perusahaan akan semakin meningkat sehingga perusahaan bisa dinilai terlalu tinggi (overvalued). Dewi \& Dewi (2016) yang mendapatkan hasil 
bahwa ada hubungan positif antara latar belakang pendidikan anggota dewan dan nilai perusahaan.

Perusahaan sektor industri dasar dan kimia meliputi industri keramik, pengolahan kertas, semen, logam, produsen makanan olahan, kimia, kemasan, dan pakan ternak. Pada tahun 2017, sektor ini berhasil mencatat pertumbuhan maksimal di Bursa Efek Indonesia yakni tumbuh sebesar 17,08\%. Hal tersebut menjadikan sektor ini sebagai sektor dengan kenaikan tertinggi kedua setelah keuangan. Selain itu, dari studi yang dilakukan oleh Credit Suisse yang menyatakan bahwa proporsi wanita dalam level CEO paling sedikit berasal dari sektor material. Pada sistem GICS, sektor material ini terdiri dari semen, kertas, kimia, bahan konstruksi, dan pertambangan mineral. Indonesia menggunakan sistem klasifikasi Jakarta Stock Industrial Classification (JASICA) pada sektor saham IHSG sehingga tidak ada sektor material. Namun, dapat dilihat bahwa sektor material ini juga mencakup beberapa rincian industri pada sektor industri dasar dan kimia. Penelitian sebelumnya sebagian besar menggunakan sektor keuangan sedangkan untuk penelitian dalam sektor industri dasar dan kimia masih jarang dilakukan.

Gender diversity merupakan bagian dari board diversity yang paling sering diteliti. Keberadaan wanita dalam level top management tidaklah banyak. Hal ini dapat disebabkan karena terdapat anggapan bahwa kompetensi dari pria dianggap lebih baik daripada wanita. Namun, wanita juga mempunyai sikap hati-hati serta ketelitian yang tinggi sehingga condong untuk bersifat risk adverse. Sifat inilah yang menyebabkan wanita untuk tidak tergesa-gesa dalam pengambilan keputusan. Karena 
ISSN: 2302-8556

E-Jurnal Akuntansi Universitas Udayana Vol.26.3.Maret (2019): 2070 -2097

hal tersebut, kehadiran wanita dalam anggota dewan dapat mempermudah untuk mengambil langkah yang cermat dan bersifat low risk.

Carter et al. (2003) serta Dewi \& Dewi (2016) menemukan adanya hubungan positif antara keberadaan wanita dalam anggota dewan pada nilai perusahaan. Lückerath-Rovers (2009) dan Ararat et al. (2010) menyatakan dengan hadirnya wanita dalam anggota dewan maka perusahaan akan mampu memiliki kinerja yang lebih bagus dibandingkan dengan perusahaan yang tidak memiliki anggota dewan wanita. Kusumastuti et al, (2007) menyatakan tidak ada hubungan diantara gender diversity dengan nilai perusahaan. Charness \& Gneezy (2010) menemukan bahwa wanita melakukan investasi yang lebih kecil pada aset berisiko dibandingkan dengan pria.

$\mathrm{H}_{1}$ : Gender diversity berpengaruh positif pada nilai perusahaan.

Anggota dewan berkebangsaan asing mempunyai pengalaman kerja yang berbeda sehingga dapat membawa opini serta perspektif yang beragam. Keberadaan anggota dewan berkebangsaan asing dapat mencerminkan pemikiran yang berbeda mengenai peran dari anggota dewan yang berkaitan dengan pengendalian perusahaan (Ararat et al., 2010). Oxelheim dan Randoy (2001) dalam Yuniasih et al., (2011) menyatakan bahwa dengan adanya anggota dewan berkebangsaan asing dapat memperlihatkan perusahaan sudah mengikuti arus globalisasi dengan melakukan proses penukaran informasi secara internasional.

Randøy et al. (2006) menyatakan terdapat keuntungan dari adanya anggota dewan berkebangsaan asing yakni: (1) terdapat kandidat anggota dewan yang 
memiliki pengalaman kerja yang luas, (2) anggota dewan berkebangsaan asing tentunya memiliki latar belakang yang berbeda sehingga dapat menambah informasi serta pengalaman yang lebih bagi perusahaan dibandingkan dengan anggota dewan domestik, serta (3) hadirnya anggota dewan berkebangsaan asing dapat membuat para investor yakin bahwa perusahaan dikelola secara profesional. S. Choi \& Hasan (2005) melakukan penelitian mengenai kinerja bank di Korea menemukan bahwa kehadiran anggota dewan asing dapat dikaitkan dengan pengembalian yang baik serta bersifat low risk.

$\mathrm{H}_{2}$ : Nationality diversity berpengaruh positif pada nilai perusahaan.

Pendidikan adalah suatu hal yang sangatlah bermanfaat bagi setiap individu. Walaupun hal tersebut tidak menjadi suatu syarat untuk seorang individu yang segera memasuki lingkungan bisnis untuk mempunyai pengetahuan ekonomi, tetapi lebih bagus apabila anggota dewan mempunyai pengetahuan di bidang tersebut. Apabila anggota dewan mempunyai pengetahuan ekonomi, setidaknya mereka memiliki kinerja yang lebih bagus dalam pengelolaan bisnis perusahaan serta dalam pengambilan keputusan investasi dibandingkan dengan anggota dewan yang tidak mempunyai pengetahuan di bidang ekonomi. Hal tersebut tentunya dapat memengaruhi nilai perusahaan.

Penelitian yang diakukan oleh Dewi \& Dewi (2016) mengindikasikan ada hubungan positif variasi latar belakang pendidikan dewan pada nilai perusahaan. Ponnu (2008) dalam Rahindayati et al. (2015) berpendapat bahwa kombinasi antara anggota dewan yang berpendidikan bisnis dengan nonbisnis dapat menjadikan 
ISSN: 2302-8556

E-Jurnal Akuntansi Universitas Udayana Vol.26.3.Maret (2019): 2070 -2097

anggota dewan yang berkompeten, sehingga hal tersebut dapat menjadi sebuah sinyal bahwa perusahaan dikelola dengan baik.

$\mathrm{H}_{3}$ : Latar belakang pendidikan anggota dewan berpengaruh positif pada nilai perusahaan.

Mace (1971) dan Spencer (1983) dalam Haniffa \& Cooke (2000) menyatakan independent commissioner merupakan bagian perusahaan yang lebih mengarah pada fungsi sebagai advisor dan bukan sebagai bagian dalam mengambil keputusan perusahaan. Tetapi, karena independensi serta sikap kebijaksanaan yang dimiliki oleh para independent commissioner, pendapat yang dikemukakan oleh mereka bisa didengarkan walaupun fungsi mereka bukanlah sebagai pembuat kebijakan perusahaan.

Matolcsy et al. (2004) dalam Kusumastuti et al. (2007) mengindikasikan apabila dewan dikuasai oleh pihak dalam perusahaan lebih condong menciptakan corporate governance yang lemah. Hal ini dapat disebabkan karena pihak dalam tersebut wajib untuk melakukan self monitoring. Sedangkan, hadirnya pihak luar dapat menciptakan corporate governance yang lebih baik karena mereka bertugas sebagai pihak independen. Raharja (2014), Dewi \& Nugrahanti (2014), serta Siallagan \& Machfoedz (2006) menemukan adanya pengaruh positif antara keberadaan dari independent commissioner dengan nilai perusahaan. Penelitian tersebut memberikan indikasi kontrol atas aktivitas dari manajemen perusahaan yang dilaksanakan oleh independent commissioner dapat meminimalisir terjadinya agency conflict yang kemudian dapat berpengaruh pada nilai perusahaan. 
$\mathrm{H}_{4}$ : Proporsi outside directors berpengaruh positif pada nilai perusahaan.

\section{METODE PENELITIAN}

Penyusunan desain penelitian dirancang untuk menuntun para peneliti dalam memperoleh hasil penelitian. Bentuk dari desain penelitian ini adalah sebagai berikut.

\begin{tabular}{|c|c|c|}
\hline $\begin{array}{l}\text { Kajian Teori } \\
\text { 1.Teori agensi (agency } \\
\text { theory) } \\
\text { 2.Teori sinyal (signalling } \\
\text { theory) } \\
\text { 3.Teori ketergantungan } \\
\text { terhadap sumber daya } \\
\text { 4.Corporate governance } \\
\text { 5.Nilai perusahaan } \\
\text { 6.Board diversity }\end{array}$ & Kumusan Masalah & \begin{tabular}{l}
\multicolumn{1}{c}{ Kajian Empiris } \\
Ararat et al. (2010) \\
Black et al. $(2002)$ \\
Carter et al. $(2003)$ \\
Kusumastuti etal. (2007) \\
Lückerath-Rovers (2009) \\
Pfeffer \& Salancik(1978) \\
Rahindayati et al. (2015) \\
Ross (1977) \\
Siciliano(1996) \\
Spence(1973) \\
Wijaya \& Suprasto (2015)
\end{tabular} \\
\hline
\end{tabular}

Gambar 1. Desain Penelitian

Sumber: Data diolah, 2018

Penelitian berlokasi pada perusahaan manufaktur sektor industri dasar dan kimia yang listing di Bursa Efek Indonesia (BEI). Objek penelitian yakni nilai perusahaan pada sektor industri dasar dan kimia yang listing di BEI. Studi ini terdapat lima variabel yakni nilai perusahaan $(\mathrm{Y})$, gender diversity $\left(\mathrm{X}_{1}\right)$, nationality diversity $\left(\mathrm{X}_{2}\right)$, latar belakang pendidikan $\left(\mathrm{X}_{3}\right)$, dan proporsi outside directors $\left(\mathrm{X}_{4}\right)$. 
ISSN: 2302-8556

E-Jurnal Akuntansi Universitas Udayana

Vol.26.3.Maret (2019): 2070 -2097

Rasio Tobin's $Q$ adalah alat yang dipergunakan dalam menghitung variabel nilai perusahaan pada studi ini. Pengukuran ini didasarkan atas penelitian Darmawati (2004).

$$
T O B I N ' S Q=\frac{(\text { MVE }+ \text { Debt })}{\text { Total Aset }}
$$

Keterangan :

MVE : Market value dari lembar saham beredar

Debt : Total liabilitas perusahaan

TA : Total aset perusahaan

Gender diversity dihitung dengan membagi total anggota dewan wanita dengan jumlah keseluruhan anggota dewan. Pengukuran ini didasarkan atas penelitian Ararat et al. 2010.

Keberadaan anggota dewan berkebangsaan asing dihitung dengan menggunakan dummy. Apabila ada warga negara asing (Amerika dan Eropa) dalam jajaran anggota dewan diberi angka 1 namun jika tidak ada diberi angka 0 . Nationality diversity diukur dengan perhitungan yang diadopsi dari Kusumastuti et al. (2007).

Latar belakang pendidikan didapat dari menghitung proporsi dari anggota dewan yang mempunyai pendidikan ekonomi dan bisnis. Proksi ini diadopsi dari penelitian Kusumastuti et al. (2007).

Proporsi outside directors dihitung dengan membagi jumlah independent commissioner dengan total anggota dewan komisaris. Proksi ini didasarkan atas Kusumastuti et al. (2007). 
Proporsi KI $=\underline{\mathrm{KI}} \times 100 \%$

DK

Keterangan:

$\mathrm{KI}=$ total independent commissioner

DK = total anggota dewan komisaris

Berdasarkan jenisnya, data yang digunakan dalam penelitian ini adalah data kuantitatif. Data kuantitatif yang digunakan dalam penelitian ini adalah jumlah wanita dalam anggota dewan, jumlah anggota dewan yang berkebangsaan asing (Amerika dan Eropa), dan jumlah anggota komisaris independen yang diambil dari annual report perusahaan manufaktur sektor industri dasar dan kimia yang terdaftar di Bursa Efek Indonesia tahun 2015-2017.

Menurut sumbernya, penelitian ini menggunakan data sekunder eksternal. Data sekunder eksternal dalam penelitian ini adalah data annual report yang diperoleh melalui website Bursa Efek Indonesia (www.idx.co.id) tahun 2015-2017 serta mengakses website resmi perusahaan yang bersangkutan.

Populasi adalah wilayah generalisasi yang terdiri atas obyek atau subyek yang mempunyai kualitas dan karakteristik tertentu yang ditetapkan oleh peneliti untuk dipelajari, dan kemudian ditarik kesimpulannya (Sugiyono, 2017: 115). Populasi dalam penelitian ini adalah seluruh perusahaan manufaktur sektor industri dasar dan kimia yang terdaftar dalam Bursa Efek Indonesia selama periode 20152017.

Sampel adalah bagian dari jumlah dan karakteristik yang dimiliki oleh populasi (Sugiyono, 2017: 116). Metode purposive sampling adalah pengambilan 
ISSN: 2302-8556

E-Jurnal Akuntansi Universitas Udayana

Vol.26.3.Maret (2019): 2070 -2097

sampel yang didasarkan atas pertimbangan subyektif peneliti, dimana terdapat syarat yang harus dipenuhi oleh sampel (Sugiyono, 2017: 122). Sampel penelitian dipilih dengan metode purposive sampling dimana kriterianya yakni: (1) Perusahaan konsisten mempublikasikan laporan tahunan selama periode 2015-2017, (2) Terdapat data mengenai profil dari anggota dewan (jenis kelamin, kebangsaan, dan latar belakang pendidikan) serta jumlah komisaris perusahaan. Sampel penelitian ini berjumlah 39 perusahaan dengan jumlah pengamatan sebanyak 117 sampel. Proses penyeleksian sampel dapat dilihat pada Tabel 1 sebagai berikut.

\section{Tabel 1.}

Proses Penyeleksian Sampel Perusahaan

\begin{tabular}{|c|c|c|}
\hline No & Kriteria & Jumlah Perusahaan \\
\hline 1 & $\begin{array}{l}\text { Perusahaan manufaktur sektor industri } \\
\text { dasar dan kimia yang terdaftar di Bursa } \\
\text { Efek Indonesia selama periode } \\
\text { pengamatan 2015-2017 }\end{array}$ & 68 \\
\hline 2 & $\begin{array}{l}\text { Perusahaan manufaktur sektor industri } \\
\text { dasar dan kimia yang tidak terdaftar } \\
\text { sebelum } 1 \text { Januari } 2015 \text { atau baru listing di } \\
\text { BEI. }\end{array}$ & (6) \\
\hline 3 & $\begin{array}{l}\text { Data pada annual report tidak tersedia atau } \\
\text { tidak lengkap }\end{array}$ & (23) \\
\hline \multicolumn{2}{|c|}{ Jumlah Sampel Akhir } & 39 \\
\hline \multicolumn{2}{|c|}{ Tahun Pengamatan } & 3 \\
\hline \multicolumn{2}{|c|}{ Jumlah Pengamatan } & 117 \\
\hline
\end{tabular}

Tabel 1 menunjukkan bahwa terdapat 68 perusahaan manufaktur sektor industri dasar dan kimia yang terdaftar di BEI selama periode 2015-2017. Terdapat 6 perusahaan yang tidak terdaftar sebelum 1 Januari 2015 atau perusahaan yang baru listing di BEI khususnya sektor industri dasar dan kimia yakni Aneka Gas Industri 
Tbk (AGII), Kirana Megatara Tbk (KMTR), Mark Dynamics Indonesia Tbk (MARK), Emdeki Utama Tbk (MDKI), Panca Budi Idaman Tbk (PBID), dan Waskita Beton Precast Tbk (WSBP). Terdapat 23 perusahaan manufaktur sektor industri dasar dan kimia yang tidak memiliki data yang diperlukan oleh peneliti secara lengkap.

Metode pengumpulan data yakni observasi nonpartisipan. Teknik analisis data yaitu multiple linear regression dengan menggunakan program Statistical Product and Service Solution (SPSS) versi 19. Persamaan uji regresi linear berganda pada penelitian ini adalah sebagai berikut.

$$
\mathrm{Y}=\alpha+\beta_{1} \mathrm{X}_{1}+\beta_{2} \mathrm{X}_{2}+\beta_{3} \mathrm{X}_{3}+\beta_{4} \mathrm{X}_{4}+\mathrm{e}
$$

Keterangan:

$\begin{array}{ll}\mathrm{Y} & =\text { nilai perusahaan } \\ \alpha & =\text { konstanta } \\ \beta_{1}, \beta_{2}, \beta_{3}, \beta_{4} & =\text { koefisien regresi } \\ \mathrm{X}_{1} & =\text { gender diversity } \\ \mathrm{X}_{2} & =\text { nationality diversity } \\ \mathrm{X}_{3} & =\text { latar belakang pendidikan } \\ \mathrm{X}_{4} & =\text { proporsi outside directors } \\ \mathrm{e} & =\text { error }\end{array}$

\section{HASIL DAN PEMBAHASAN}

Statistik deskriptif dalam penelitian ini disajikan untuk memberikan informasi mengenai karakteristik variabel-variabel penelitian berupa nilai rata-rata (mean), deviasi standar (standard deviation), dan nilai maksimum serta nilai minimum. Hasil statistik deskriptif mengenai pengaruh board diversity pada nilai perusahaan disajikan pada Tabel 2 sebagai berikut. 
ISSN: 2302-8556

E-Jurnal Akuntansi Universitas Udayana

Vol.26.3.Maret (2019): 2070 -2097

Tabel 2.

Hasil Analisis Statistik Deskriptif

\begin{tabular}{lrrrrr}
\hline & N & Minimum & Maximum & \multicolumn{1}{l}{ Mean } & \multicolumn{1}{c}{ Std. Deviation } \\
\hline Y & 117 & 0.5 & 1.64 & 0.96983 & 0.253064 \\
X1 & 117 & 0 & 0.33 & 0.10718 & 0.090228 \\
X2 & 117 & 0 & 1 & 0.43 & 0.497 \\
X3 & 117 & 0.2 & 1 & 0.52573 & 0.177887 \\
X4 & 117 & 0 & 0.8 & 0.39368 & 0.136966 \\
Valid N (listwise) & 117 & & & & \\
\hline
\end{tabular}

Sumber: Data diolah, 2018

Tabel 2 memperlihatkan jumlah sampel (N) yang digunakan dalam penelitian ini adalah sebanyak 117 yang terdiri dari 39 perusahaan manufaktur sektor industri dasar dan kimia yang terdaftar di Bursa Efek Indonesia dengan periode tiga tahun yaitu pada tahun 2015-2017 yang diteliti dengan menggunakan nilai perusahaan sebagai variabel terikat serta gender diversity, nationality diversity, latar belakang pendidikan dewan, dan proporsi outside directors sebagai variabel bebas.

Hasil statistik deskriptif menunjukkan bahwa variabel nilai perusahaan memiliki nilai maksimum sebesar 1,640; nilai minimum sebesar 0,500 ; nilai rata-rata sebesar 0,96983; dan standar deviasi sebesar 0,253064. Nilai maksimum sebesar 1,640 berarti perusahaan tersebut dinilai 1,64 kali lipat dari nilai buku perusahaan dan nilai minimum sebesar 0,500 berarti perusahaan tersebut hanya dinilai setengah dari nilai buku perusahaan. Rata-rata nilai perusahaan dianggap tidak menarik, karena rasio Tobin's $Q$ dibawah satu.

Hasil statistik deskriptif untuk variabel gender diversity menunjukkan nilai minimum sebesar 0 yang memiliki arti bahwa perusahaan tidak memiliki anggota 
dewan wanita di perusahaan dan nilai maksimum sebesar 0,330 yang dimiliki oleh perusahaan BRPT (Barito Pacific Tbk) pada tahun 2015 dan 2016 yang berarti bahwa sebanyak 33\% anggota dewan dalam perusahaan tersebut adalah wanita. Nilai ratarata dari gender diversity adalah 0,10718 dan standar deviasi sebesar 0,090228. Nilai rata-rata ini menunjukkan bahwa masih sedikitnya persentase wanita dalam anggota dewan di perusahaan manufaktur sektor industri dasar dan kimia.

Hasil statistik deskriptif menunjukkan bahwa variabel nationality diversity memiliki nilai maksimum sebesar 1 dan nilai minimum 0 , nilai rata-rata sebesar 0,43 dan standar deviasinya yaitu sebesar 0,479. Nilai rata-rata variabel nationality diversity lebih kecil dari standar deviasinya menunjukkan bahwa adanya warga negara asing (Amerika dan Eropa) dalam anggota dewan yang diwakilkan dengan kode 1 lebih sedikit muncul dari 117 perusahaan sampel yang diteliti atau hanya 50 perusahaan yang memiliki warga negara asing (Amerika dan Eropa).

Hasil statistik deskriptif untuk variabel latar belakang pendidikan menunjukkan nilai minimum sebesar 0,2 yang dimiliki oleh perusahaan TBMS (Tembaga Mulia Semanan Tbk) dan TIRT (Tirta Mahakam Resources Tbk) pada tahun 2015-2017 serta IGAR (Champion Pacific Indonesia Tbk) pada tahun 2015 memiliki arti bahwa sebesar $20 \%$ anggota dewan perusahaan memiliki latar belakang pendidikan ekonomi dan bisnis. Nilai maksimum variabel latar belakang pendidikan yakni sebesar 1 yang dimiliki oleh perusahaan ALKA (Alakasa Industrindo Tbk) pada tahun 2015 dan 2017 yang memiliki arti bahwa semua anggota dewan perusahaan memiliki latar 
ISSN: 2302-8556

E-Jurnal Akuntansi Universitas Udayana

Vol.26.3.Maret (2019): 2070 -2097

belakang pendidikan ekonomi dan bisnis. Nilai rata-rata dari variabel latar belakang pendidikan adalah 0,52573 dan standar deviasi sebesar 0,177887. Nilai rata-rata sebesar 0,52573 menunjukkan bahwa sebagian besar anggota dewan dari perusahaan manufaktur sektor industri dasar dan kimia memiliki latar belakang ekonomi dan bisnis.

Hasil statistik deskriptif menunjukkan bahwa variabel proporsi outside directors memiliki nilai maksimum sebesar 0,8 dan nilai minimum 0 , nilai rata-rata sebesar 0,39368 dan standar deviasinya yaitu sebesar 0,136966. Nilai minimum sebesar 0 memiliki arti bahwa masih ada perusahaan yang tidak memiliki anggota komisaris independen dalam perusahaannya. Perusahaan tersebut yakni ALKA (Alakasa Industrindo Tbk) dan TRST (Trias Sentosa Tbk). Hal ini menunjukkan bahwa kedua perusahaan sampel tersebut tidak memenuhi syarat jumlah komisaris independen yang telah ditetapkan oleh Bursa Efek Indonesia (BEI) yakni minimal 30 persen dari jumlah total komisaris perusahaan. Nilai maksimum sebesar 0,8 memiliki arti bahwa $80 \%$ dari anggota komisaris perusahaan tersebut merupakan komisaris independen. Nilai rata-rata variabel proporsi outside directors sebesar 0,39368 memiliki arti bahwa sebagian besar perusahaan sudah memenuhi syarat jumlah minimal dari komisaris independen yang ditetapkan oleh BEI.

Setelah dilakukan analisis statistik deskriptif, maka akan dilakukan uji asumsi klasik. Pembahasan hasil uji asumsi klasik adalah sebagai berikut. 
Tabel 3.

Hasil Uji Normalitas

\begin{tabular}{llr}
\hline & & $\begin{array}{c}\text { Unstandardized } \\
\text { Residual }\end{array}$ \\
\hline $\mathrm{N}$ & & 117 \\
Normal Parameters (a,b) & Mean & 0.0000000 \\
& Std. Deviation & 0.23630126 \\
Most Extreme & Absolute & 0.084 \\
Differences & Positive & 0.084 \\
& Negative & -0.049 \\
Kolmogorov-Smirnov Z & & 0.909 \\
Asymp. Sig. (2-tailed) & & 0.381 \\
\hline Sumber: Data diolah, 2018 & &
\end{tabular}

Nilai Asymp. Sig. (2-tailed) sebesar 0,381 >0,05, yang mengindikasikan bahwa data berdistribusi normal.

Tabel 4.

\section{Hasil Uji Autokorelasi}

\begin{tabular}{rrrrrr}
\hline Model & $\mathrm{R}$ & $\begin{array}{c}\mathrm{R} \\
\text { Square }\end{array}$ & $\begin{array}{c}\text { Adjusted R } \\
\text { Square }\end{array}$ & $\begin{array}{c}\text { Std. Error of } \\
\text { the Estimate }\end{array}$ & $\begin{array}{c}\text { Durbin- } \\
\text { Watson }\end{array}$ \\
\hline 1 & 0.358 & 0.128 & 0.097 & 0.240484 & 2.128 \\
\hline
\end{tabular}

Sumber: Data diolah, 2018

Nilai dari Durbin Watson lebih besar daripada nilai $\mathrm{d}_{\mathrm{u}}=0,72$ dan kurang dari

3,28 $\left(4-\mathrm{d}_{\mathrm{u}}\right)$, sehingga tidak terdapat gejala autokorelasi.

Tabel 5.

Hasil Uji Multikolinearitas

\begin{tabular}{rlcc}
\hline \multirow{2}{*}{ Model } & & \multicolumn{2}{c}{ Colinearity Statistics } \\
& & & Tolerance \\
\hline 1 & (Constant) & 0.805 & 1.242 \\
& Gender D & 0.832 & 1.202 \\
& Nationality D & 0.831 & 1.203 \\
& Pendidikan & 0.895 & 1.118 \\
& Proporsi O.D & &
\end{tabular}

Sumber: Data diolah, 2018 
ISSN: 2302-8556

E-Jurnal Akuntansi Universitas Udayana Vol.26.3.Maret (2019): 2070 -2097

Nilai tolerance gender diversity $\left(\mathrm{X}_{1}\right)$, nationality diversity $\left(\mathrm{X}_{2}\right)$, latar belakang pendidikan $\left(\mathrm{X}_{3}\right)$, dan proporsi outside directors $\left(\mathrm{X}_{4}\right)>0.10$ serta nilai VIF untuk gender diversity $\left(\mathrm{X}_{1}\right)$, nationality diversity $\left(\mathrm{X}_{2}\right)$, latar belakang pendidikan $\left(\mathrm{X}_{3}\right)$, dan proporsi outside directors $\left(\mathrm{X}_{4}\right)<10$. Hal ini mengindikasikan model penelitian bebas dari multikolinearitas.

\section{Tabel 6.}

\section{Hasil Uji Heteroskedastisitas}

\begin{tabular}{lcccrl}
\hline \multicolumn{7}{c}{$\begin{array}{c}\text { Unstandardized } \\
\text { Coefficients }\end{array}$} & \multicolumn{2}{c}{$\begin{array}{c}\text { Standardized } \\
\text { Coefficients }\end{array}$} & & \\
Model & $\mathrm{B}$ & Std. Error & Beta & \multicolumn{1}{c}{ t } & Sig. \\
\hline (Constant) & 0.193 & 0.060 & & 3.226 & 0.002 \\
Gender D & -0.065 & 0.147 & -0.045 & -0.440 & 0.660 \\
Nationality D & -0.006 & 0.026 & -0.021 & -0.214 & 0.831 \\
Pendidikan & 0.126 & 0.073 & 0.173 & 1.720 & 0.088 \\
Proporsi O D & -0.136 & 0.092 & -0.143 & -1.478 & 0.142 \\
\hline Sumber: Data diolah, 2018 & & & &
\end{tabular}

Nilai signifikansi gender diversity $\left(\mathrm{X}_{1}\right)$, nationality diversity $\left(\mathrm{X}_{2}\right)$, latar belakang pendidikan $\left(\mathrm{X}_{3}\right)$, dan proporsi outside directors $\left(\mathrm{X}_{4}\right)>0,05$ sehingga dalam model penelitian tersebut tidak menunjukkan heteroskedastisitas.

Berdasarkan Tabel 7 maka hasil regresi linear berganda yang dipergunakan yakni.

$$
Y=0,872-0,143 X_{1}+0,110 X_{2}+0,297 X_{3}-0,228 X_{4}+e
$$


Tabel 7.

Hasil Analisis Regresi Linear Berganda

\begin{tabular}{lccccc}
\hline \multicolumn{7}{c}{$\begin{array}{c}\text { Unstandardized } \\
\text { Coefficients }\end{array}$} & $\begin{array}{c}\text { Standardized } \\
\text { Coefficients }\end{array}$ & & \\
Model & $\mathrm{B}$ & Std. Error & Beta & $\mathrm{t}$ & Sig. \\
\hline (Constant) & 0.872 & 0.112 & & 7.786 & 0.000 \\
Gender D & -0.143 & 0.276 & -0.051 & -0.519 & 0.605 \\
Nationality D & 0.11 & 0.049 & 0.215 & 2.224 & 0.028 \\
Pendidikan & 0.297 & 0.138 & 0.209 & 2.156 & 0.033 \\
Proporsi O D & -0.228 & 0.172 & -0.124 & -1.325 & 0.188 \\
Adjusted R & 0.097 & & & & \\
Square & 0.004 & & & & \\
Sig. F & & & & & \\
Sumber: Data diolah, 2018 & & & & &
\end{tabular}

Nilai konstanta 0,872 mengindikasikan apabila gender diversity, nationality diversity, latar belakang pendidikan, dan proporsi outside directors dianggap konstan (nol), maka variabel nilai perusahaan akan naik 0,872 . Nilai regression coefficient $\mathrm{X}_{1}$ sebesar -0,143 memiliki arti, jika variabel gender diversity turun 1 lalu variabel nilai perusahaan naik 0,143 . Nilai regression coefficient $\mathrm{X}_{2}$ sebesar 0,110 memiliki arti jika variabel nationality diversity naik 1 lalu variabel nilai perusahaan diharapkan naik 0,110 .

Nilai regression coefficient $\mathrm{X}_{3}$ sebesar 0,297 memiliki arti jika variabel latar belakang pendidikan naik 1 lalu variabel nilai perusahaan diharapkan naik 0,297. Nilai regression coefficient $\mathrm{X}_{4}$ sebesar $-0,228$ memiliki arti, jika variabel proporsi outside directors turun 1 lalu variabel nilai perusahaan diharapkan naik 0,228.

Nilai Adjusted R Square 0.097 menunjukkan 9,7\% naik dan turunnya nilai perusahaan dipengaruhi oleh variasi dari gender diversity, nationality diversity, latar belakang pendidikan, dan proporsi outside directors. Berdasarkan Tabel 5, nilai 
ISSN: 2302-8556

E-Jurnal Akuntansi Universitas Udayana Vol.26.3.Maret (2019): 2070 -2097

signifikansi $\mathrm{F}$ atau $p$-value sebesar 0,004. Nilai ini kurang dari signifikansi 0,05 yang berarti model yang dipergunakan bersifat layak uji.

Hipotesis pertama $\left(\mathrm{H}_{1}\right)$ menyatakan bahwa gender diversity berpengaruh positif pada nilai perusahaan. Hasil analisis dengan menggunakan multiple linear regression menunjukkan gender diversity yang dihitung dengan membagi total anggota dewan wanita dengan jumlah keseluruhan anggota dewan memiliki tingkat signifikansi 0,605 dimana nilai ini lebih besar dari nilai alpha 5\% $(0,605>0,05)$. Berdasarkan hasil tersebut, tidak ada pengaruh antara gender diversity pada nilai perusahaan.

Kusumastuti et al, (2007) mendapatkan hasil yang sama dengan penelitian ini dimana tidak ada hubungan diantara gender diversity dengan nilai perusahaan. Fenomena ini dapat diakibatkan akibat karakteristik dari wanita bersifat risk adverse. Akibatnya, dalam beberapa jabatan penting wanita memiliki persentase yang lebih kecil daripada pria (Charness \& Gneezy, 2010). Charness \& Gneezy (2010) juga menemukan bahwa wanita melakukan investasi yang lebih kecil pada aset berisiko dibandingkan dengan pria. Penelitian ini tidak sejalan dengan Carter et al. (2003), Lückerath-Rovers (2009), Ararat et al. (2010), serta Dewi \& Dewi (2016).

Hipotesis kedua $\left(\mathrm{H}_{2}\right)$ menyatakan bahwa nationality diversity berpengaruh positif pada nilai perusahaan. Hasil analisis dengan menggunakan multiple linear regression menunjukkan nationality diversity yang diukur dengan menggunakan dummy memiliki tingkat signifikansi sebesar 0,028 yaitu kurang dari $(\alpha)=5 \%$ 
$(0,028<0,05)$. Hal ini menunjukkan bahwa nationality diversity berpengaruh pada nilai perusahaan. Arah koefisien regresi variabel nationality diversity dalam penelitian ini bertanda positif sebesar 0,110 . Hal tersebut berarti bahwa semakin banyak terdapat warga negara asing (Amerika dan Eropa) dalam anggota dewan, maka nilai perusahaan akan semakin meningkat sehingga hipotesis kedua pada penelitian ini dapat diterima.

Ararat et al, (2010) menyatakan bahwa semakin banyak persentase warga negara asing dalam anggota dewan maka harapan dari para pelaku pasar mengenai kelangsungan hidup perusahaan akan semakin meningkat sehingga perusahaan bisa dinilai terlalu tinggi (overvalued). S. Choi \& Hasan (2005) melakukan penelitian mengenai kinerja bank di Korea menemukan bahwa kehadiran anggota dewan asing dapat dikaitkan dengan pengembalian yang baik dan bersifat low risk.

Hipotesis ketiga $\left(\mathrm{H}_{3}\right)$ menyatakan bahwa latar belakang pendidikan berpengaruh positif pada nilai perusahaan. Hasil analisis dengan menggunakan multiple linear regression menunjukkan latar belakang pendidikan yang didapat dari menghitung proporsi dari anggota dewan yang mempunyai pendidikan ekonomi dan bisnis memiliki tingkat signifikansi sebesar 0,033 yaitu kurang dari $(\alpha)=5 \%$ $(0,033<0,05)$. Hal ini menunjukkan bahwa latar belakang pendidikan berpengaruh pada nilai perusahaan. Arah koefisien regresi variabel latar belakang pendidikan dalam penelitian ini bertanda positif sebesar 0,297. Hal tersebut berarti bahwa semakin banyak terdapat anggota dewan yang memiliki latar belakang di bidang 
ISSN: 2302-8556

E-Jurnal Akuntansi Universitas Udayana

Vol.26.3.Maret (2019): 2070 -2097

ekonomi dan bisnis, maka nilai perusahaan akan semakin meningkat sehingga hipotesis kedua pada penelitian ini dapat diterima.

Hasil ini sejalan dengan Dewi \& Dewi (2016) yang mendapatkan hasil bahwa ada hubungan positif antara latar belakang pendidikan anggota dewan dan nilai perusahaan. Ponnu (2008) dalam Rahindayati et al. (2015) berpendapat bahwa kombinasi antara anggota dewan yang berpendidikan bisnis dengan nonbisnis dapat menjadikan anggota dewan yang berkompeten, sehingga hal tersebut dapat menjadi sebuah sinyal bahwa perusahaan dikelola dengan baik.

Hipotesis keempat $\left(\mathrm{H}_{4}\right)$ menyatakan bahwa proporsi outside directors berpengaruh positif pada nilai perusahaan. Hasil analisis dengan menggunakan regresi linear berganda menunjukkan proporsi outside directors yang diukur dengan membandingkan jumlah komisaris independen dengan jumlah seluruh anggota dewan komisaris, memiliki tingkat signifikansi sebesar 0,188 yaitu lebih besar dari $(\alpha)=5 \%$ $(0,188>0,05)$. Hasil tersebut menjelaskan bahwa tidak ada hubungan diantara proporsi outside directors dengan nilai perusahaan sehingga hipotesis keempat pada penelitian ini ditolak.

Hasil ini sejalan dengan Dewi \& Dewi (2016), Kusumastuti et al, (2007), dan Wijaya \& Suprasto (2015) yang menemukan hasil keberadaan outside directors tidak berpengaruh pada nilai perusahaan. Terdapat hal menarik mengenai independensi dari dewan komisaris di Indonesia dimana terdapat fenomena bahwa jabatan komisaris independen diberikan kepada seseorang bukan karena kompetensi atau profesionalisme, melainkan karena aspek penghormatan dan penghargaan 
(Kusumastuti et al., 2007). Berdasarkan hal tersebut, keberadaan komisaris independen tidak memberikan pengaruh pada peningkatan kualitas aktivitas pengawasan tindakan manajemen (Wijaya \& Suprasto, 2015). Penelitian ini tidak sejalan dengan Raharja (2014), Dewi \& Nugrahanti (2014), serta Siallagan \& Machfoedz (2006) yang mendapatkan adanya pengaruh positif antara keberadaan dari independent commissioner dengan nilai perusahaan.

Implikasi teoretis yakni dapat memberi tambahan informasi dalam kajian mengenai board diversity pada nilai perusahaan. Penelitian ini juga mengonfirmasi teori agensi (agency theory). Agency theory menyebutkan bahwa terdapat pemisahaan kepemilikan antara principal dan agent. Pemisahan kepemilikan ini akan dapat menimbulkan konflik, dimana untuk mengatasi konflik tersebut maka perusahaan harus mengeluarkan biaya agensi. Corporate governance sering kali digunakan sebagai alat untuk mengontrol biaya agensi yang timbul dalam perusahaan.

Implikasi praktis penelitian ini yaitu dapat memberikan masukan bagi perusahaan mengenai pengaruh board diversity pada nilai perusahaan sehingga diharapkan nilai perusahaan akan semakin meningkat. Bagi para investor untuk dapat mempertimbangkan diversitas pengurus perusahaan sebelum melakukan investasi. Bagi regulator untuk dapat mempertimbangkan penetapan regulasi mengenai komposisi pengurus sebuah perusahaan sebagai bentuk perlindungan bagi investor. 
ISSN: 2302-8556

E-Jurnal Akuntansi Universitas Udayana

Vol.26.3.Maret (2019): 2070 -2097

\section{SIMPULAN}

Berdasarkan empat pengujian atas hipotesis penelitian dapat disimpulkan bahwa adanya pengaruh positif antara variabel nationality diversity dan latar belakang pendidikan dengan nilai perusahaan. Hasil ini yang berarti apabila keberadaan warga negara asing (Amerika dan Eropa) dalam anggota dewan serta anggota dewan yang memiliki pengetahuan ekonomi dan bisnis meningkat maka nilai perusahaan akan meningkat juga. Sedangkan, tidak adanya pengaruh antara variabel gender diversity dan proporsi outside directors dengan nilai perusahaan menunjukkan bahwa kehadiran wanita serta independent commissioner dalam anggota dewan tidak dianggap sebagai suatu mekanisme yang mampu membuat kinerja perusahaan semakin baik di mata para investor sehingga keberadaan wanita serta independent commissioner dalam perusahaan tidak direspon oleh pasar.

Saran serta rekomendasi yang dapat diberikan oleh peneliti yakni: (1) Penelitian berikutnya bisa meneliti pada objek lain contohnya pada sektor keuangan. (2) Nilai Adjusted $R$ Square yakni 0,097 atau sebesar 9,7\%. Hasil tersebut menunjukkan terdapat beberapa variabel yang dapat memengaruhi board diversity pada nilai perusahaan. Berdasarkan hasil penelitian, variabel board diversity yang dapat memengaruhi nilai perusahaan yakni umur anggota dewan (Ararat et al., 2010), keberadaan minoritas (Kusumastuti et al., 2007), dan proporsi anggota muda dalam dewan (Darmadi, 2010). 


\section{REFERENSI}

Ararat, M., Aksu, M. H., \& Tansel Cetin, A. (2010). The Impact of Board Diversity on Boards' Monitoring Intensity and Firm Performance: Evidence from the Istanbul Stock Exchange. Ssrn, 90(216). https://doi.org/10.2139/ssrn.1572283

Black, B. S., Jang, H., \& Kim, W. (2002). Does corporate governance affect firm value? - Evidence from Korea. 2002 RIETI Corporate Governance Conference.

Carter, D. A., Simkins, B. J., Simpson, W. G., Borokhovich, K., Crutchley, C., Elson, C., ... Longhofer, S. (2003). Corporate Governance, Board Diversity, and Firm Value. The Financial Review, 38, 33-53. https://doi.org/10.1111/15406288.00034

Charness, G., \& Gneezy, U. (2010). Strong Evidence for Gender Differences in Investment. https://doi.org/10.2139/ssrn.648735

Choi, S., \& Hasan, I. (2005). Ownership, Governance, and Bank Performance: Korean Experience. Financial Markets, Institutions \& Instruments, 14(4), 215242.

Darmawati, D. (2004). Hubungan Corporate Governance dan Kinerja Perusahaan. Simposium Nasional Akuntansi VII Bali, 2-3.

Dewi, L. C., \& Nugrahanti, Y. W. (2014). Pengaruh Struktur Kepemilikan dan Dewan Komisaris Independen terhadap Nilai Perusahaan (Studi pada Perusahaan Industri Barang Konsumsi di Bei Tahun 2011-2013). Jurnal Kinerja, 18(1), 64-80.

Dewi, L. G. K., \& Dewi, A. A. (2016). Pengaruh Diversitas Dewan Komisaris Dan Direksi Pada Nilai Perusahaan Pada Perusahaan Sektor Keuangan Yang Terdaftar Di Bursa Efek Indonesia Tahun 2009-2013. E-Jurnal Akuntansi Universitas Udayana, 16, 812-836.

Haniffa, R., \& Cooke, T. (2000). Culture, Corporate Governance and Disclosure in Malaysian Corporations, 2000 (August), 28-30.

Kusumastuti, S., Supatmi, \& Sastra, P. (2007). Pengaruh Board Diversity Terhadap Nilai Perusahaan Dalam Perspektif Corporate Governance. Jurnal Akuntansi Dan Keuangan, 9(2), 88-98. Retrieved from http://puslit2.petra.ac.id/ejournal/index.php/aku/article/view/16819 
ISSN: 2302-8556

E-Jurnal Akuntansi Universitas Udayana Vol.26.3.Maret (2019): 2070 -2097

Lückerath-Rovers, M. (2009). Female Directors On Corporate Boards Provide Legitimacy To A Company. A Resource Dependency Perspective. Erasmus University Rotterdam, 1-23.

McKinsey \& Company. (2002). Global Investor Opinion. New York:Oxford University Press, (August). Retrieved from http://www.eiod.org/uploads/Publications/Pdf/II-Rp-4-1.pdf

Pfeffer, J., \& Salancik, G. R. (1978). The External Control of Organizations: A Resource Dependence Perspective. New York, 263(814), 521-532. https://doi.org/10.2307/2392573

Raharja, R. S. P. (2014). Analisis Pengaruh Corporate Governance Terhadap Nilai Perusahaan. Diponegoro Journal Of Accounting, 3(3), 1-13. https://doi.org/ISSN (Online): 2337-806

Rahindayati, N. M., Ramantha, I. W., \& Rasmini, N. K. (2015). Pengaruh Diversitas Pengurus Pada Luas Pengungkapan Corporate Social Responsibility Perusahaan Sektor Keuangan. E-Jurnal Ekonomi Dan Bisnis Universitas Udayana, 4(5), 312-330. https://doi.org/10.1108/SAMPJ-10-2013-0042

Randøy, T., Thomsen, S., \& Oxelheim, L. (2006). A Nordic perspective on corporate board diversity. Nordic Innovation Centre, (November), 1-34.

Ratih, I. D. A., \& Damayanthi, I. G. A. E. (2016). Kepemilikan Manajerial Dan Profitabilitas Pada Nilai Perusahaan Dengan Pengungkapan Tanggungjawab Sosial Sebagai Variabel Pemoderasi. E-Jurnal Akuntansi Universitas Udayana, 13(2), 1510-1538.

Riyanda, M. P. P., \& Indriani, S. (2013). Hubungan Financial Distress \& Mekanisme GCG Terhadap Pelaporan Audit pada Susi Indriyani Perusahaan Perbankan yang Terdaftar di Bursa Efek Indonesia Periode 2005-2010, XI, 1-19.

Siallagan, H., \& Machfoedz, M. (2006). Mekanisme Corporate Governance, Kualitas Laba dan Nilai Perusahaan. Simposium Nasional Akuntansi 9 Padang, (61), 2326.

Siciliano, J. I. (1996). The relationship of board member diversity to organizational performance. Journal of Business Ethics, 15(12), 1313-1320. https://doi.org/10.1007/BF00411816

Sugiyono. (2017). Metode Penelitian Bisnis (Pendekatan Kuantitatif, Kualitatif, Kombinasi, dan R\&D). CV Alfabeta: Bandung. 
Wijaya, P. C., \& Suprasto, B. (2015). Pengaruh Persebaran Dewan Two Tier (Dewan Gabungan) Pada Nilai Perusahaan Sektor Keuangan. E-Jurnal Akuntansi Universitas Udayana, 12(3), 722-734.

Yuniasih, N. W., Rasmini, N. K., \& Wirakusuma, M. G. (2011). Pengaruh Diversitas Dewan pada Luas Pengungkapan Modal Intelektual. Simposium Nasional Akuntansi XIV Aceh, pp 1-29. 